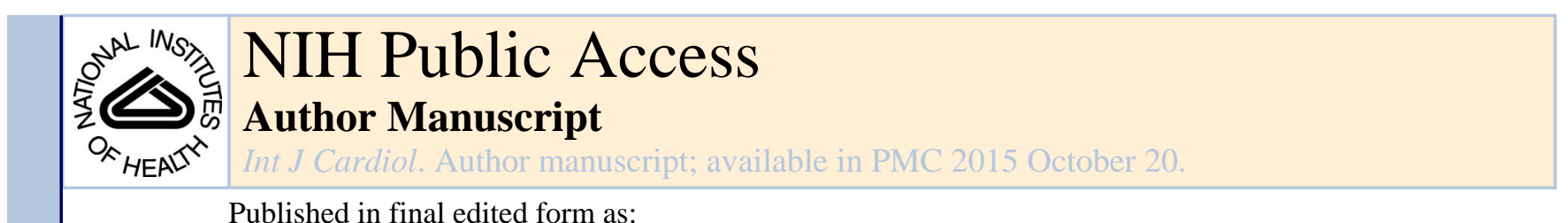

Published in final edited form as:

Int J Cardiol. 2014 October 20; 176(3): 611-617. doi:10.1016/j.ijcard.2014.08.007.

\title{
Obesity and Natriuretic Peptides, BNP and NT-proBNP: Mechanisms and Diagnostic Implications for Heart Failure
}

\author{
Chaitanya Madamanchi ${ }^{\mathrm{a}}$, Hassan Alhosaini ${ }^{\mathrm{b}}$, Arihiro Sumida ${ }^{\mathrm{a}}$, and Marschall S. Runge ${ }^{\mathrm{a}}$ \\ aDepartment of Medicine, University of North Carolina at Chapel Hill, NC, USA \\ bEast Carolina Heart Institute, Greenville, NC, USA
}

\begin{abstract}
Many advances have been made in the diagnosis and management of heart failure (HF) in recent years. Cardiac biomarkers are an essential tool for clinicians: point of care B-Type Natriuretic Peptide (BNP) and its N-terminal counterpart (NT-proBNP) levels help distinguish cardiac from non-cardiac causes of dyspnea and are also useful in the prognosis and monitoring of the efficacy of therapy. One of the major limitations of HF biomarkers is in obese patients where the relationship between BNP and NT-proBNP levels and myocardial stiffness is complex. Recent data suggest an inverse relationship between BNP and NT-proBNP levels and body mass index. Given the ever-increasing prevalence of obesity world-wide, it is important to understand the benefits and limitations of HF biomarkers in this population. This review will explore the biology, physiology, and pathophysiology of these peptides and the cardiac endocrine paradox in HF. We also examine the clinical evidence, mechanisms, and plausible biological explanations for the discord between BNP levels and HF in obese patients.
\end{abstract}

\author{
Keywords \\ BNP; Obesity; Heart Failure; BMI; Adiposity
}

\section{Introduction}

The obesity pandemic is a leading cause of morbidity and mortality across the world. In the United States an estimated one-third of Americans are obese, presenting a significant and growing public health concern [1]. Obesity is a risk factor for systemic hypertension, hyperlipidemia, diabetes mellitus, and left ventricular hypertrophy. These conditions, in turn, are associated with an increased prevalence of chronic heart failure (CHF), which results in the death of about half of the patient population within 5 years of diagnosis [2,3]. An estimated 5.1 million people are living with CHF in the United States, costing about $\$ 32$

(C) 2014 Elsevier Ireland Ltd. All rights reserved.

Correspondence: Marschall S. Runge, MD, PhD, McAllister Heart Institute, Department of Medicine, University of North Carolina, 125 MacNaider Hall, Chapel Hill, NC 27599-7005, Phone: 919-843-6485, Fax: 919-843-5945, marschall_runge@med.unc.edu.

Publisher's Disclaimer: This is a PDF file of an unedited manuscript that has been accepted for publication. As a service to our customers we are providing this early version of the manuscript. The manuscript will undergo copyediting, typesetting, and review of the resulting proof before it is published in its final citable form. Please note that during the production process errors may be discovered which could affect the content, and all legal disclaimers that apply to the journal pertain. 
billion in health care costs and loss of productivity [3]. CHF is a progressive disease whose management requires close monitoring of the patient's clinical status.

Obese patients, however, present unique challenges in the diagnosis of CHF, particularly in the emergency department (ED) settings [4-6]. Obesity may mask signs of edema and auscultation may be difficult during physical examination [6]. Obese patients may also present dyspnea and orthopnea, characteristic symptoms of $\mathrm{CHF}$, from deconditioning and abdominal size, respectively. In addition, body habitus also diminishes the image quality of echocardiograms and chest radiographs [7,8]. Consequently, the use of molecular biomarkers to aid in the diagnosis and management of CHF would be particularly valuable in obese patients. The circulating biomarkers for myocardial stiffness, the brain natriuretic peptides BNP and NT-proBNP, are used to establish or exclude the diagnosis of CHF in patients with acute dyspnea in the ED. Higher natriuretic peptide levels increase the likelihood that etiology of dyspnea is due to HF [9]. However, the use of these markers is compromised in obese patients as their levels tend to be lower. In this review, we will discuss the biochemistry, physiology, and clinical use of BNP and NT-proBNP in obese patients with CHF. Finally, we will explore the biological basis underlying the inverse relationship between BNP and NT-proBNP levels and obesity.

\section{B-Type Natriuretic Peptide}

BNP belongs to a family of natriuretic peptides, which includes atrial natriuretic peptide (ANP) and C-type natriuretic peptide (CNP), with the latter mainly secreted by vascular endothelium. ANP and BNP are cardiac natriuretic peptides secreted by myocytes, with BNP mainly secreted by atrial myocytes in the normal heart [10,11]. Ventricular BNP secretion increases drastically in CHF, indicative of greater ventricular stress and serious cardiac dysfunction [12-14]. The precursor of human BNP, preproBNP, is 134 amino acids (aa) in length and is a theoretically deduced form which does not exist as a separate entity [14]. PreproBNP is processed to 108 aa proBNP by the cleavage of $\mathrm{N}$-terminal 26 aa signal peptide. The proBNP is cleaved by serine endoproteases corin and furin into an inactive 76 aa N-terminal peptide, NT-proBNP and a C-terminal 32 aa long active hormone, BNP [15]. BNP contains a ring structure formed by a disulfide bond between the cysteine residues Cys10 and Cys26, which is essential for receptor binding and biological activity [16]. In addition to NT-proBNP and BNP, unprocessed proBNP also circulates in the plasma, whose levels may be more compared with the cleavage products in severe HF [14].

Cardiac natriuretic peptides are released from the heart under physiological conditions and are involved in cardiovascular homeostasis [17-19]. This is achieved, in part, by integrating the function of renal system. Natriuretic peptides induce dilation of afferent and constriction of efferent renal arterioles, resulting in increased glomerular filtration and enhanced natriuresis and diuresis [20,21]. In addition, these peptides decrease cardiac preload by shifting intravascular fluid into the interstitial space [22]. Natriuretic peptides suppress renin-angiotensin-aldosterone system (RAAS) and the release of renin from the kidney and aldosterone from the adrenal gland, which enhances natriuresis and the reduction of extracellular volume [23-25]. 
Natriuretic peptides suppress sympathetic nerve activity in the peripheral vasculature, perhaps by lowering the activation threshold of baroreceptors, by suppressing catecholamine release from the nerve endings, and by the inhibition of the sympathetic outflow [21,26-28]. Because these peptides lower the activation threshold of vagal afferents, reflex tachycardia and vasoconstriction that follow reduction in the preload are suppressed, effecting a sustained decrease in mean arterial pressure. Relaxation of smooth muscle cells and suppression of RAAS induced by the natriuretic peptides decrease systemic and peripheral vascular resistance [29]. Furthermore, natriuretic peptides may function as endogenous inhibitors of cardiac hypertrophy and fibrosis [30,31].

Natriuretic peptide secretion increases in proportion to the severity of the left ventricular dysfunction, suggesting that end-diastolic wall stress is the main regulatory mechanism $[32,33]$. However, increased peptide levels are also found in patients with renal failure or pulmonary hypertension and may increase in arterial hypertension or liver cirrhosis [34]. Increased BNP levels were reported in patients with acute coronary syndrome or during exercise-induced ischemia, in the absence of significant ventricular dilation [35-38]. Plasma ANP levels were chronically elevated following cardiac transplantation even after the return of cardiac function and normalization of RAAS [39]. These observations suggest an active involvement of the neurohormonal and immune systems in the regulation of the natriuretic peptide levels, which is supported by in vitro and animal model studies. For example, angiotensin II and endothelin induced BNP synthesis in rat cardiomyocytes as well as in anaesthetized rats [40]. Similarly, plasma natriuretic peptide levels were increased in rat experimental autoimmune myocarditis [41]. In addition, proinflammatory cytokines tumor necrosis factor- $\alpha$, interleukin- $1 \beta$, and interleukin- 6 induce BNP synthesis in cardiomyocytes $[42,43]$. These data suggest a complex interaction among mechanical, neurohormonal, and immunological components in the regulation of cardiac endocrine response involving natriuretic peptide synthesis/secretion.

Compared with the healthy subjects, a progressive increase in median BNP levels of up to 57-fold and median NT-proBNP levels of up to 107-fold was observed in patients with HF (discussed later) in NYHA class IV/stage D [44]. Despite the direct diuretic and natriuretic effects of natriuretic peptides, congestion, sodium retention, and edema are the hallmarks of CHF [14]. This cardiac endocrine paradox suggests a blunted biological effect of the peptides, mainly on natriuresis, which can be attributed to three main mechanisms [38, 45]. First, the blunted effect may result from impaired post-translational processing of biosynthetic precursors of BNP [14,46-50]. Consistent with this, Dong et al. [49] reported a significant decrease in the plasma levels of corin involved in proBNP processing, in CHF patients compared with the healthy controls, with the decrease in the enzyme level correlated with the severity of the disease. Increased levels of proBNP, with reduced efficacy in the activation of NPR-A receptor (discussed later) compared with BNP, can impair natriuresis [51]. In addition, the resistance of proBNP to degradation may result in the increased proBNP:BNP ratio observed in CHF patients, contributing to peripheral resistance to the biological activation of natriuretic peptides. Second, altered expression of natriuretic peptide receptors might also contribute to resistance to the biological effect of the peptides in CHF [52-55]. Another potential mechanism of resistance includes homologous desensitization of the NPR-A receptor [38], protein kinase C-dependent heterologous 
desensitization of NPR-A by vasoconstrictive hormones [56], increased activity of phosphodiesterases that hydrolyze cGMP $[57,58]$ and the refractory nature of NPR-A to natriuretic peptide stimulation [59].

\section{Clinical Use of BNP and NT-proBNP}

In the 1990s, the advent of assays for measuring serum levels of BNP allowed researchers to investigate the use of BNP as a clinical biomarker for CHF [60]. A large number of studies showed strong evidence for the use of BNP levels to aid in the diagnosis of HF in patients who present with acute dyspnea. In 2005, Wang et al. conducted a meta-analysis to evaluate the diagnostic value of circulating BNP levels [61]. They found that, across a pool of eleven studies, high BNP levels ( $>250 \mathrm{pg} / \mathrm{mL}$ ) increased the chances of CHF by $2-4.5$ times. Additionally, moderate to low BNP levels $(<250 \mathrm{pg} / \mathrm{mL})$ were associated with a $90 \%$ decrease in the incidence of CHF [60,61]. The validity of using BNP levels to diagnose HF in the emergent setting was also supported by the large-scale multi-center Breathing Not Properly (BNP) Study, which evaluated 1586 patients who presented with acute dyspnea [4]. This study found that patients diagnosed with CHF had significantly higher BNP levels (mean BNP $675 \mathrm{pg} / \mathrm{mL}$ ) than patients with base-line left ventricular dysfunction but other causes of dyspnea (mean BNP $346 \mathrm{pg} / \mathrm{mL}$ ) or no left ventricular dysfunction or HF (mean BNP $110 \mathrm{pg} / \mathrm{mL}$ ). Based on this, Maisel et al. [4] established the widely used standard of BNP level $>100 \mathrm{pg} / \mathrm{mL}$ as a cutoff for CHF as the etiology for acute dyspnea in the emergent setting (sensitivity $90 \%$ and specificity $76 \%$ ) (Table 1).

Using a design similar to the above mentioned BNP study, in the N-Terminal Pro-BNP Investigation of Dyspnea in the Emergency Department (PRIDE) study Januzzi et al. [62] investigated the utility of NT-proBNP for the diagnosis of CHF in 600 dyspnea patients, a cohort with a final diagnosis of $35 \%$ acute CHF. An age-stratified analysis determined a rule-in cut point of $450 \mathrm{pg} / \mathrm{mL}$ for patients $<50$ years (sensitivity $93 \%$ and specificity $95 \%$ ) and $900 \mathrm{pg} / \mathrm{mL}$ for patients $\geq 50$ years (sensitivity $91 \%$ and specificity $80 \%$ ). More recently, Hildebrandt et al. [63] further refined age-based cut points for NT-proBNP levels after analyzing data of 5508 primary care patients from 10 studies in several countries. NTproBNP values of $50 \mathrm{ng} / \mathrm{L}$ (sensitivity $99.2 \%$, specificity $57.2 \%$, and negative predictive value $99.7 \%$ ), $75 \mathrm{ng} / \mathrm{L}$ (sensitivity $95.9 \%$, specificity $51.0 \%$, and negative predictive value $96.8 \%$ ), and $250 \mathrm{ng} / \mathrm{L}$ (sensitivity $87.9 \%$, specificity $53.7 \%$, and negative predictive value $92.4 \%$ ) for $<50,50-75$, and $>75$ years, respectively, were superior to a single cut point to rule out HF. Emphasizing the importance of age stratification in improving diagnostic sensitivity, the data from the International Collaborative of NT-proBNP (ICON) study identified rule in cut points for acute $\mathrm{HF}$ of 450,900 , and $1800 \mathrm{pg} / \mathrm{mL}$ for patients aged $<50$, $50-75$, and $>75$ years, respectively ( $90 \%$ sensitivity and $84 \%$ specificity) [64] (Table 1). However, an age-independent cut point of $300 \mathrm{pg} / \mathrm{mL}$ of NT-proBNP was sufficient to rule out acute HF, demonstrating 99, 60, and 98\% of sensitivity, specificity, and negative predictive value, respectively.

Both the BNP and PRIDE studies show that BNP and NT-proBNP levels in combination with clinical judgment are superior to natriuretic factors levels or clinical judgment alone, indicating the importance of integrating the testing of these peptides with clinical assessment 
for the diagnosis of CHF in patients who present with dyspnea in the emergency department $[62,65]$. Supporting this notion, in a prospective study of 3870 older men NT-proBNP improved prediction of CHF above routine conventional risk factors and the Health $\mathrm{ABC}$ Heart Failure Score in all men and in men with and without established CVD $(\mathrm{P}<0.0001$ for improvement in c-statistics [66]. However, the consensus is that natriuretic peptide level is not a stand-alone test and as a quantitative marker, it is better used as a continuous variable in the treatment of CHF [9]. While left ventricular ejection fraction $<40 \%$ is considered a threshold for causing chronic systolic HF, 40-50\% of HF patients have normal ejection fractions without an apparent systolic dysfunction [67-69]. HF patients with ejection fractions $>45$ or $50 \%$ are referred to as having "HF with preserved systolic function" (HFPSF) or "nonsystolic HF" [70,71]. BNP levels also help distinguish patients with HFPSF from those without $\mathrm{HF}$, although a measurement of LV function is necessary distinguish between HFPSF from systolic HF [70]. Similarly, increased NT-proBNP levels indicate increased risk for both systolic HR and HFPSF [72].

In addition to its utility in CHF diagnosis, several studies have established that circulating BNP levels are a powerful prognostic indicator in HF. Anand et al. analyzed data from the Valsartan Heart Failure Trial (Val-HeFT) of $\sim 4300$ patients to evaluate the predictive power of BNP levels [73]. Their data revealed that levels above $97 \mathrm{pg} / \mathrm{mL}$ are associated with twice the risk of morbidity and mortality. Additionally, Tsutamoto et al. found, in a prospective study of 290 patients with asymptomatic or minimally symptomatic left ventricular dysfunction, that plasma BNP levels $>56 \mathrm{pg} / \mathrm{mL}$ were an independent predictor for mortality [74].

Owing to its strong diagnostic and prognostic power, there has been great interest in using BNP to guide individual patient management. In the aforementioned Val-HeFT study, patients with the largest increase in BNP from the pre-treatment baseline had the highest mortality, whereas those with greatest decline the lowest mortality [73,75]. Similarly, a study by Jourdain et al. examined the relative effectiveness of established dosing guidelines against dosing based on changes in BNP levels for angiotensin-converting enzyme inhibitors, beta-blockers, and diuretics in the treatment of CHF [76]. Over a 15 month period, the group that received BNP-guided dosing had significantly reduced risk of CHFrelated death or hospital stay for CHF ( $24 \%$ vs. $52 \%, \mathrm{P}<0.001)$. These promising early reports invite further study as they suggest an exciting and innovative way to personalize CHF treatment approaches to individual patients.

\section{The Relationship Between BMI and BNP}

There are many variables that affect BNP levels in a patient, including gender and age [77], hypertension [78], renal disease [79], and atrial fibrillation [80]. The increase in natriuretic peptide levels with age likely reflects age-related decreases in left ventricular compliance [81] and glomerular filtration rate [82]. Recently, researchers have demonstrated a consistent inverse relationship between obesity (defined as having a BMI of 30 or greater) and circulating BNP levels. Wang et al. [83] were the first to describe the inverse relationship between obesity and BNP levels in a study of 3389 subjects from the original Framingham Heart Study offspring cohort, none of whom had HF. Multivariable regression analysis was 
adjusted for echocardiographic variables such as left ventricular mass and left atrial size. The mean plasma BNP levels were 21.4, 15.5 , and $12.7 \mathrm{pg} / \mathrm{mL}$ in lean (BMI<25), overweight (BMI of 25 to 29.9), and obese (BMI greater than or equal to 30), respectively. One important limitation of this study was its cross-sectional design and it was not possible to determine whether the low BNP levels preceded or followed the development of obesity.

Examination of a large population-based cohort of the Dallas Heart Study confirmed the report of Wang et al. [83], demonstrating the inverse relationship among BMI, BNP, and NT-proBNP levels. This study included 2707 patients, who were randomly selected residents of Dallas County, aged 30 to 65 [84]. The association between obesity and low BNP values ( $<4 \mathrm{ng} / \mathrm{L}$ ), or low NT-proBNP (lowest sex-specific quartile; $<7.6 \mathrm{ng} / \mathrm{L}$ for men and $<20.4 \mathrm{ng} / \mathrm{L}$ for women) evaluated with multivariable regression models adjusted for age, gender, ethnicity, left ventricular mass, hypertension, and end diastolic volume showed that higher BMI values were associated with lower BNP and NT-proBNP levels $(\mathrm{P}<0.001)$. However, upon replacement of BMI with direct dual energy $\mathrm{x}$-ray absorptiometry-derived lean and fat mass, higher lean mass correlated more closely with low BNP and NT-proBNP levels. Decreased NT-proBNP levels were also observed in obese patients with stable as well as acute CHF [85,86]. In contrast, after adjusting for age and sex in a multivariate analysis of participating residents of Olmsted County, MN, BMI had no significant effect on NT-proBNP levels in an apparently healthy cohort of 746 subjects [87].

The Suita study examined 1759 subjects from urban areas in Japan, without heart disease, to determine if the inverse relationship between BMI and BNP existed among a population with lower BMIs versus those in Western countries, where more studies on this subject have been done [88]. The subjects ranged from 38 to 95 years of age with a mean BMI of 22.8. Multivariable regression analysis, adjusting for age, pulse rate, serum creatinine, systolic blood pressure, and left ventricular hypertrophy, showed an inverse relationship between BMI and BNP levels in both sexes $(\mathrm{P}<0.01)$. The Suita study is particularly interesting because it demonstrated that the inverse relationship between BMI and BNP remains valid in a cross-cultural setting. This will rule out the involvement of confounding dietary or lifestyle factors in regulating BNP levels.

\section{The biological link between obesity and BNP}

A number of hypotheses have been put forth in an attempt to explain the inverse relationship between obesity and circulating BNP levels. However, to date there has been no conclusive evidence in favor of any particular hypothesis.

\section{Kidneys}

Renal function, more specifically glomerular filtration rate, has been reported to depress BNP levels in obese CHF patients [89] because obesity is associated with substantially higher glomerular filtration rates [90]. This suggests that obese patients may have depressed circulating BNP levels simply because they are clearing these molecules more effectively. Given the short half-life of BNP ( 23 minutes), this explanation is plausible. However the Suita study argues against this theory as their multivariable regression analysis was adjusted 
for serum creatinine among other variables, and still found the inverse relationship between BMI and BNP [88].

\section{Adipose Tissue}

Adipose tissue expansion is one of the defining characteristics of obesity. Adipocytes are known to highly express natriuretic peptide clearance receptors-C (NPR-C), causing some to speculate that this is the basis for low serum BNP levels associated with obesity [91,92]. However, the Dallas Heart Study showed that obesity is also linked with lower levels of NTproBNP, which is not cleared by the NPR-C [84]. Additionally, the Dallas Heart Study found that BNP and NT-proBNP levels were more closely correlated with lean mass than with BMI, suggesting that adipose tissue itself may not be the driving force in this relationship. The authors postulate that a substance produced in the lean mass either suppresses the synthesis or release of the natriuretic peptides or an androgen coordinately regulates natriuretic peptide synthesis and body composition. Alternatively, the fat mass measured by dual energy $\mathrm{x}$-ray absorptiometry in this study might mostly consist of subcutaneous adipose tissue [93]. In a study of 1873 community-based individuals, Cheng et al. [94] found an inverse relationship between NT-proBNP levels and visceral adipose mass, which was attenuated after adjustment for HOMA-IR (homeostasis model assessment of insulin resistance), indicating a role for hyperinsulinemia in lower natriuretic peptide levels in obesity. These data are consistent with the reports that hyperinsulinemia attenuates natriuretic peptide secretion and activity $[95,96]$. However, acute insulin administration has either no significant effect [97] or increased [98] natriuretic peptide levels, indicating perhaps the differential physiological effects of acute vs chronic hyperinsulinemia on natriuretic peptide levels.

Interestingly, several investigators have postulated a 'bidirectional relationship' between BNP and adiposity because BNP has been shown to cause lipolysis in adipocytes (Figure 1). They point out that low levels of BNP could lead to less lipolysis and thus promote obesity [92,93]. Supporting this hypothesis, Cabiati et al. [99] recently reported significantly lower levels of BNP and a reduction of ANP and CNP mRNA levels in the hearts of obese compared with the control rats. Furthermore, BNP induced lipolysis may underlie the wasting (cardiac cachexia) seen in patients with severe HF [92]. Natriuretic peptides exert their biological effects via stimulation of NPR-A (GC-A/NPR-1) and NPR-B (GC-B/ NPR-2), two receptors which act as membrane-bound guanylyl cyclases [100]. ANP and BNP preferentially bind to NPR-A, where CNP is a physiological ligand for NPR-B [101]. Stimulation of these receptors generates cyclic guanosine monophosphate (cGMP) and subsequent activation of cGMP-dependent protein kinase 1 (cGK1), which constitute the nitric oxide signal transduction pathway [102].

Using three types of genetically engineered mouse models - BNP transgenic, cGK transgenic and NPR-A heterozygous knockout mice- Miyashita et al. [102] demonstrated that increased natriuretic peptide levels prevent accumulation of abdominal fat in mice on high fat diet, by promoting mitochondrial biogenesis in skeletal muscle, through increased expression of peroxisome proliferator-activated receptor (PPAR)- $\gamma$ coactivator (PGC)-1a and PPAR $\delta$, via the activation of $\mathrm{cGMP/cGK1}$ signaling cascade (Figure 1). In addition, 
BNP transgenic mice were protected against diet-induced insulin resistance. Cardiac natriuretic peptides also induced mitochondrial biogenesis by increasing the expression of PGC-1a and PPAR $\delta$ in C2C12 myotubes. More importantly, high fat diet decreased the expression of NPR-A and NPR-B and increased the expression of NPR-C in skeletal muscle, brown and white adipose tissue. A low NPR-A:NPR-C ratio could decrease natriuretic peptide induced cGMP/cGK1 signaling pathways as well as natriuretic peptide levels within the tissue $[103,104]$.

In tune with the above data, natriuretic peptides activated PGC-1a, induced mitochondriogenesis, and increased respiration in human adipocytes [105]. Additionally, infusion of BNP into mice significantly increased the expression of uncoupling protein 1 , a mediator of thermogenic energy expenditure and PGC-1a in adipose tissue, suggesting a role in regulation of obesity. In this context, it is of interest to note that calorie restriction promotes muscle mitochondrial biogenesis in rodents [106] as well as humans [107] by increasing the levels of nitric oxide, the upstream activator of cGMP/cGK1 pathway. Emerging evidence suggests that natriuretic peptides control lipolysis and lipid mobilization in physiological and pathological conditions [108]. Further supporting the protective effect of natriuretic peptides against obesity, Sengenés et al. [92] reported that cardiac natriuretic peptides induce strong lipolysis in isolated human fat cells by producing cGMP via the NPR-A receptor. Activation of $\mathrm{cGMP} / \mathrm{cGK} 1$ pathway increases the phosphorylation of perilipin-A and hormone-sensitive lipase, a rate-limiting enzyme in lipolysis [109]. Perilipin-A phosphorylation results in the physical alteration of the surface of the lipid droplet, facilitating the binding of the hormone-sensitive lipase and hydrolysis of triglycerides into free fatty acids and glycerol.

Congruent with this data, a meta-analysis of 49279 subjects from seven case-controlled studies showed that BNP promoter T-381C polymorphism (rs198389), associated with higher BNP levels, has modest protective effect against type 2 diabetes [110]. However, this polymorphism is not associated with a decreased HF risk in large population based-cohort studies, indicating that increase in BNP levels because of the genetic variation might not be large enough to cause clinically detectable risk reduction [111,112]. Supporting the role of natriuretic peptides in adiposity, significant increases in the levels of BNP and NT-proBNP were observed in obese patients following gastric bypass surgery [113,114]. Similarly, weight loss as a result of comprehensive lifestyle changes in patients with coronary heart disease and coronary heart disease risk factors and/or diabetes mellitus decreased insulin and increased BNP levels [115], suggesting that loss of natriuretic peptide clearance pathways as well as hyperinsulinemia regulate natriuretic peptide levels.

\section{Validity of BNP as a marker for CHF in Obese Patients}

Because obese subjects have BNP levels below the traditional cutoff used to diagnose CHF, lower thresholds should be used to diagnose HF in this patient population [6]. Based on the established clinical threshold of $100 \mathrm{pg} / \mathrm{mL}$, BNP testing yielded false negative results in $20 \%$ of obese HF patients $[6,116]$. Hence, a cut point of BNP $\leq 54 \mathrm{pg} / \mathrm{mL}$ is recommended for ruling out CHF in severely obese patients (BMI 235) (Table 1) [6]. It is also suggested that a higher BNP cut point of $\geq 170 \mathrm{pg} / \mathrm{mL}$ in lean patients increases specificity. In contrast 
to BNP cut points, relatively lower concentrations NT-proBNP in overweight and obese patients with acute dyspnea retain their diagnostic and prognostic capacity [117]. A cut point of $300 \mathrm{ng} / \mathrm{L}$ NT-proBNP had highly significant negative likelihood ratio of 0.02, 0.03, and 0.08 for BMI of <25.0, 25.0-29.9, and 230.0 , respectively, ruling out acute HF. Also, a NTproBNP cut point of $>986 \mathrm{ng} / \mathrm{L}$ remained strongly prognostic across all 3 BMI groups.

\section{Conclusions}

HF has become the most common cardiovascular diagnosis in hospitalized patients and, at the same time, the proportion of HF patients with significant obesity has increased dramatically due to the increase in obesity in the general population. For this reason, more precise understanding on the inter-relationship between BMI and BNP measurements is of critical importance and will facilitate more accurate diagnosis of HF in obese patients. In this review, we have illustrated new knowledge on important relationships that exist between natriuretic peptides and lipid metabolism as well as the regulation of natriuretic peptide secretion and activity in normal body weight and obesity. Further basic and translational research offers the possibility of formulating new therapeutic strategies for treatment of vascular and metabolic diseases in general and CHF in particular.

\section{Acknowledgments}

Funding Sources

This work was supported in part by NIH grants HL111664 and TR000083.

\section{References}

1. Flegal KM, Carroll MD, Ogden CL, Curtin LR. Prevalence and trends in obesity among US adults, 1999-2008. JAMA. 2010; 303:235-241. [PubMed: 20071471]

2. The National Task Force on the Prevention and Treatment of Obesity. Overweight, obesity, and health risk. Arch Intern Med. 2000; 160:898-904. [PubMed: 10761953]

3. Go AS, Mozaffarian D, Roger VL, Benjamin EJ, Berry JD, Blaha MJ, Dai S, Ford ES, Fox CS, Franco S, Fullerton HJ, Gillespie C, Hailpern SM, Heit JA, Howard VJ, Huffman MD, Judd SE, Kissela BM, Kittner SJ, Lackland DT, Lichtman JH, Lisabeth LD, Mackey RH, Magid DJ, Marcus GM, Marelli A, Matchar DB, McGuire DK, Mohler ER 3rd, Moy CS, Mussolino ME, Neumar RW, Nichol G, Pandey DK, Paynter NP, Reeves MJ, Sorlie PD, Stein J, Towfighi A, Turan TN, Virani SS, Wong ND, Woo D, Turner MB. American Heart Association Statistics Committee and Stroke Statistics Subcommittee. Executive summary: heart disease and stroke statistics--2014 update: a report from the American Heart Association. Circulation. 2014; 129:399-410. [PubMed: 24446411]

4. Maisel AS, Krishnaswamy P, Nowak RM, Mak E, Ayas NT. Rapid measurement of B-type natriuretic peptide in the emergency diagnosis of heart failure. N Engl J Med. 2002; 347:161-167. [PubMed: 12124404]

5. Maisel A, Hollander JE, Guss D, McCullough P, Nowak R, Green G, Saltzberg M, Ellison SR, Bhalla MA, Bhalla V, Clopton P, Jesse R. Rapid Emergency Department Heart Failure Outpatient Trial investigators. Primary results of the Rapid Emergency Department Heart Failure Outpatient Trial (REDHOT). A multicenter study of B-type natriuretic peptide levels, emergency department decision making, and outcomes in patients presenting with shortness of breath. J Am Coll Cardiol. 2004; 44:1328-1333. [PubMed: 15364340]

6. Daniels LB, Clopton P, Bhalla V. How obesity affects the cut-points for B-type natriuretic peptide in the diagnosis of acute heart failure. Results from the Breathing Not Properly Multinational Study. Am Heart J. 2006; 151:999-1005. [PubMed: 16644321] 
7. Savage DD, Garrison RJ, Kannel WB, Anderson SJ, Feinleib M, Castelli WP. Considerations in the use of echocardiography in epidemiology. The Framingham Study. Hypertension. 1987; 9:II40 1144. [PubMed: 3804399]

8. Finkelhor RS, Moallem M, Bahler RC. Characteristics and impact of obesity on the outpatient echocardiography laboratory. Am J Cardiol. 2006; 97:1082-1084. [PubMed: 16563921]

9. Maisel A, Mueller C, Adams K Jr, Anker SD, Aspromonte N, Cleland JG, Cohen-Solal A, Dahlstrom U, DeMaria A, Di Somma S, Filippatos GS, Fonarow GC, Jourdain P, Komajda M, Liu PP, McDonagh T, McDonald K, Mebazaa A, Nieminen MS, Peacock WF, Tubaro M, Valle R, Vanderhyden M, Yancy CW, Zannad F, Braunwald E. State of the art: using natriuretic peptide levels in clinical practice. Eur J Heart Fail. 2008; 10:824-839. [PubMed: 18760965]

10. Luchner A, Stevens TL, Borgeson DD, Redfield M, Wei CM, Porter JG, Burnett JC Jr. Differential atrial and ventricular expression of myocardial BNP during evolution of heart failure. Am $\mathrm{J}$ Physiol. 1998; 274:H1684-H1689. [PubMed: 9612380]

11. Christoffersen C, Goetze JP, Bartels ED, Larsen MO, Ribel U, Rehfeld JF, Rolin B, Nielsen LB. Chamber-dependent expression of brain natriuretic peptide and its mRNA in normal and diabetic pig heart. Hypertension. 2002; 40:54-60. [PubMed: 12105138]

12. Mukoyama M, Nakao K, Hosoda K, Suga S, Saito Y, Ogawa Y, Shirakami G, Jougasaki M, Obata $\mathrm{K}$, Yasue H, Kambayashi Y, Inouye K, Imura H. Brain natriuretic peptide as a novel cardiac hormone in humans. Evidence for an exquisite dual natriuretic peptide system, atrial natriuretic peptide and brain natriuretic peptide. J Clin Invest. 1991; 87:1402-1412. [PubMed: 1849149]

13. Mehra R, Maisel A. B-Type Natriuretic Peptide in Heart Failure: Diagnostic, Prognostic, and Therapeutic Use. Critical Pathways in Cardiology. 2005; 4:10-20. [PubMed: 18340179]

14. Goetze JP. Biosynthesis of cardiac natriuretic peptides. Results Probl Cell Differ. 2010; 50:97-120. [PubMed: 19859677]

15. Semenov AG, Tamm NN, Seferian KR, Postnikov AB, Karpova NS, Serebryanaya DV, Koshkina EV, Krasnoselsky MI, Katrukha AG. Processing of pro-B-type natriuretic peptide: furin and corin as candidate convertases. Clin Chem. 2010; 56:1166-1176. [PubMed: 20489134]

16. Misono KS, Fukumi H, Grammer RT, Inagami T. Rat atrial natriuretic factor: complete amino acid sequence and disulfide linkage essential for biological activity. Biochem Biophys Res Commun. 1984; 119:524-529. [PubMed: 6538787]

17. de Bold AJ, Bruneau BG, Kuroski de Bold ML. Mechanical and neuroendocrine regulation of the endocrine heart. Cardiovasc Res. 1996; 31:7-18. [PubMed: 8849584]

18. de Bold AJ, Ma KK, Zhang Y, de Bold ML, Bensimon M, Khoshbaten A. The physiological and pathophysiological modulation of the endocrine function of the heart. Can J Physiol Pharmacol. 2001; 79:705-714. [PubMed: 11558679]

19. Costello-Boerrigter LC, Lapp H, Boerrigter G, Lerman A, Bufe A, Macheret F, Heublein DM, Larue C, Burnett JC. Secretion of Prohormone of B-Type Natriuretic Peptide, proBNP $1-108$, Is Increased in Heart Failure. JCHF. 2013; 1:207-212.

20. Marin-Grez M, Fleming JT, Steinhausen M. Atrial natriuretic peptide causes pre-glomerular vasodilatation and post-glomerular vasoconstriction in rat kidney. Nature. 1986; 324:473-476. [PubMed: 2946962]

21. Levin ER, Gardner DG, Samson WK. Natriuretic peptides. N Engl J Med. 1998; 339:321-328. [PubMed: 9682046]

22. Wijeyaratne CN, Moult PJ. The effect of alpha human atrial natriuretic peptide on plasma volume and vascular permeability in normotensive subjects. J Clin Endocrinol Metab. 1993; 76:343-346. [PubMed: 8432776]

23. Hunt PJ, Espiner EA, Nicholls MG, Richards AM, Yandle TG. Differing biological effects of equimolar atrial and brain natriuretic peptide infusions in normal man. J Clin Endocrinol Metab. 1996; 81:3871-3876. [PubMed: 8923831]

24. Kurtz A, Della Bruna R, Pfeilschifter J, Taugner R, Bauer C. Atrial natriuretic peptide inhibits renin release from juxtaglomerular cells by a cGMP-mediated process. Proc Natl Acad Sci U S A. 1986; 83:4769-4773. [PubMed: 3014509] 
25. Apfeldorf WJ, Isales CM, Barrett PQ. Atrial natriuretic peptide inhibits the stimulation of aldosterone secretion but not the transient increase in intracellular free calcium concentration induced by angiotensin II addition. Endocrinology. 1988; 122:1460-1465. [PubMed: 2964364]

26. Schultz HD, Gardner DG, Deschepper CF, Coleridge HM, Coleridge JC. Vagal C-fiber blockade abolishes sympathetic inhibition by atrial natriuretic factor. Am J Physiol. 1988; 255:R6-13. [PubMed: 2969196]

27. Yang RH, Jin HK, Wyss JM, Chen YF, Oparil S. Pressor effect of blocking atrial natriuretic peptide in nucleus tractus solitarii. Hypertension. 1992; 19:198-205. [PubMed: 1531332]

28. Brunner-La Rocca HP, Kaye DM, Woods RL, Hastings J, Esler MD. Effects of intravenous brain natriuretic peptide on regional sympathetic activity in patients with chronic heart failure as compared with healthy control subjects. J Am Coll Cardiol. 2001; 37:1221-1227. [PubMed: 11300426]

29. Saito Y, Nakao K, Nishimura K, Sugawara A, Okumura K, Obata K, Sonoda R, Ban T, Yasue H, Imura $\mathrm{H}$. Clinical application of atrial natriuretic polypeptide in patients with congestive heart failure: beneficial effects on left ventricular function. Circulation. 1987; 76:115-124. [PubMed: 2954723]

30. Horio T, Nishikimi T, Yoshihara F, Matsuo H, Takishita S, Kangawa K. Inhibitory regulation of hypertrophy by endogenous atrial natriuretic peptide in cultured cardiac myocytes. Hypertension. 2000; 35:19-24. [PubMed: 10642269]

31. Cao L, Gardner DG. Natriuretic peptides inhibit DNA synthesis in cardiac fibroblasts. Hypertension. 1995; 25:227-34. [PubMed: 7843772]

32. Yasue H, Yoshimura M, Sumida H, Kikuta K, Kugiyama K, Jougasaki M, Ogawa H, Okumura K, Mukoyama M, Nakao K. Localization and mechanism of secretion of B-type natriuretic peptide in comparison with those of A-type natriuretic peptide in normal subjects and patients with heart failure. Circulation. 1994; 90:195-203. [PubMed: 8025996]

33. Watanabe S, Shite J, Takaoka H, Shinke T, Imuro Y, Ozawa T, Otake H, Matsumoto D, Ogasawara D, Paredes OL, Yokoyama M. Myocardial stiffness is an important determinant of the plasma brain natriuretic peptide concentration in patients with both diastolic and systolic heart failure. Eur Heart J. 2006; 27:832-838. [PubMed: 16464912]

34. Mair J, Friedl W, Thomas S, Puschendorf B. Natriuretic peptides in assessment of left-ventricular dysfunction. Scand J Clin Lab Invest Suppl. 1999; 230:132-142. [PubMed: 10389212]

35. Omland T, Persson A, Ng L, O’Brien R, Karlsson T, Herlitz J, Hartford M, Caidahl K. N-terminal pro-B-type natriuretic peptide and long-term mortality in acute coronary syndromes. Circulation. 2002; 106:2913-2918. [PubMed: 12460871]

36. Foote RS, Pearlman JD, Siegel AH, Yeo KT. Detection of exercise-induced ischemia by changes in B-type natriuretic peptides. J Am Coll Cardiol. 2004; 44:1980-1987. [PubMed: 15542280]

37. Sabatine MS, Morrow DA, de Lemos JA, Omland T, Desai MY, Tanasijevic M, Hall C, McCabe $\mathrm{CH}$, Braunwald E. Acute changes in circulating natriuretic peptide levels in relation to myocardial ischemia. J Am Coll Cardiol. 2004; 44:1988-1995. [PubMed: 15542281]

38. Clerico A, Recchia FA, Passino C, Emdin M. Cardiac endocrine function is an essential component of the homeostatic regulation network: physiological and clinical implications. Am J Physiol Heart Circ Physiol. 2006; 290:H17-H29. [PubMed: 16373590]

39. Masters RG, Davies RA, Keon WJ, Walley VM, Koshal A, de Bold AJ. Neuroendocrine response to cardiac transplantation. Can J Cardiol. 1993; 9:609-617. [PubMed: 8221359]

40. Horio T, Kohno M, Takeda T. Effects of arginine vasopressin, angiotensin II and endothelin-1 on the release of brain natriuretic peptide in vivo and in vitro. Clin Exp Pharmacol Physiol. 1992; 19:575-582. [PubMed: 1526063]

41. Ogawa T, Veinot JP, Kuroski de Bold ML, Georgalis T, de Bold AJ. Angiotensin II receptor antagonism reverts the selective cardiac BNP upregulation and secretion observed in myocarditis. Am J Physiol Heart Circ Physiol. 2008; 294:H2596-H2603. [PubMed: 18408131]

42. Ma KK, Ogawa T, de Bold AJ. Selective upregulation of cardiac brain natriuretic peptide at the transcriptional and translational levels by pro-inflammatory cytokines and by conditioned medium derived from mixed lymphocyte reactions via p38 MAP kinase. J Mol Cell Cardiol. 2004; 36:505513. [PubMed: 15081310] 
43. Tanaka T, Kanda T, Takahashi T, Saegusa S, Moriya J, Kurabayashi M. Interleukin-6-induced reciprocal expression of SERCA and natriuretic peptides mRNA in cultured rat ventricular myocytes. J Int Med Res. 2004; 32:57-61. [PubMed: 14997707]

44. Emdin M, Passino C, Prontera C, Fontana M, Poletti R, Gabutti A, Mammini C, Giannoni A, Zyw L, Zucchelli G, Clerico A. Comparison of brain natriuretic peptide (BNP) and amino-terminal ProBNP for early diagnosis of heart failure. Clin Chem. 2007; 53:1289-1297. [PubMed: 17495021]

45. Baerts L, Gomez N, Vanderheyden M, De Meester I, Mc Entee K. Possible mechanisms for brain natriuretic peptide resistance in heart failure with a focus on interspecies differences and canine BNP biology. Vet J. 2012; 194:34-39. [PubMed: 23022110]

46. Liang F, O’Rear J, Schellenberger U, Tai L, Lasecki M, Schreiner GF, Apple FS, Maisel AS, Pollitt NS, Protter AA. Evidence for functional heterogeneity of circulating B-type natriuretic peptide. J Am Coll Cardiol. 2007; 49:1071-1078. [PubMed: 17349887]

47. Seferian KR, Tamm NN, Semenov AG, Mukharyamova KS, Tolstaya AA, Koshkina EV, Kara AN, Krasnoselsky MI, Apple FS, Esakova TV, Filatov VL, Katrukha AG. The brain natriuretic peptide (BNP) precursor is the major immunoreactive form of BNP in patients with heart failure. Clin Chem. 2007; 53:866-873. [PubMed: 17384012]

48. Dries DL, Ky B, Wu AH, Rame JE, Putt ME, Cappola TP. Simultaneous assessment of unprocessed ProBNP1-108 in addition to processed BNP32 improves identification of high-risk ambulatory patients with heart failure. Circ Heart Fail. 2010; 3:220-227. [PubMed: 20107190]

49. Dong N, Chen S, Yang J, He L, Liu P, Zheng D, Li L, Zhou Y, Ruan C, Plow E, Wu Q. Plasma soluble corin in patients with heart failure. Circ Heart Fail. 2010; 3:207-211. [PubMed: 20061521]

50. Del Ry S, Cabiati M, Clerico A. Recent advances on natriuretic peptide system: new promising therapeutic targets for the treatment of heart failure. Pharmacol Res. 2013; 76:190-198. [PubMed: 23988875]

51. Dickey DM, Potter LR. ProBNP(1-108) is resistant to degradation and activates guanylyl cyclaseA with reduced potency. Clin Chem. 2011; 57:1272-1278. [PubMed: 21768217]

52. Tsutamoto T, Kanamori T, Morigami N, Sugimoto Y, Yamaoka O, Kinoshita M. Possibility of downregulation of atrial natriuretic peptide receptor coupled to guanylate cyclase in peripheral vascular beds of patients with chronic severe heart failure. Circulation. 1993; 87:70-75. [PubMed: 8093432]

53. Andreassi MG, Del Ry S, Palmieri C, Clerico A, Biagini A, Giannessi D. Up-regulation of 'clearance' receptors in patients with chronic heart failure: a possible explanation for the resistance to biological effects of cardiac natriuretic hormones. Eur J Heart Fail. 2001; 3:407-414. [PubMed: $11511425]$

54. Kuhn M, Voss M, Mitko D, Stypmann J, Schmid C, Kawaguchi N, Grabellus F, Baba HA. Left ventricular assist device support reverses altered cardiac expression and function of natriuretic peptides and receptors in end-stage heart failure. Cardiovasc Res. 2004; 64:308-314. [PubMed: 15485690]

55. Singh G, Kuc RE, Maguire JJ, Fidock M, Davenport AP. Novel snake venom ligand dendroaspis natriuretic peptide is selective for natriuretic peptide receptor-A in human heart: downregulation of natriuretic peptide receptor-A in heart failure. Circ Res. 2006; 99:183-190. [PubMed: 16778132]

56. Potthast R, Potter LR. Phosphorylation-dependent regulation of the guanylyl cyclase-linked natriuretic peptide receptors. Peptides. 2005; 26:1001-1008. [PubMed: 15911068]

57. Chen HH, Huntley BK, Schirger JA, Cataliotti A, Burnett JC Jr. Maximizing the renal cyclic 3'-5'guanosine monophosphate system with type $\mathrm{V}$ phosphodiesterase inhibition and exogenous natriuretic peptide: a novel strategy to improve renal function in experimental overt heart failure. $\mathbf{J}$ Am Soc Nephrol. 2006; 17:2742-2747. [PubMed: 16928803]

58. Forfia PR, Lee M, Tunin RS, Mahmud M, Champion HC, Kass DA. Acute phosphodiesterase 5 inhibition mimics hemodynamic effects of B-type natriuretic peptide and potentiates B-type natriuretic peptide effects in failing but not normal canine heart. J Am Coll Cardiol. 2007; 49:1079-1088. [PubMed: 17349888] 
59. Dickey DM, Dries DL, Margulies KB, Potter LR. Guanylyl cyclase (GC)-A and GC-B activities in ventricles and cardiomyocytes from failed and non-failed human hearts: GC-A is inactive in the failed cardiomyocyte. J Mol Cell Cardiol. 2012; 52:727-732. [PubMed: 22133375]

60. Felker G, Peterson J, Mark D. Natriuretic peptides in the diagnosis and management of heart failure. CMAJ. 2006; 175:611-617. [PubMed: 16966666]

61. Wang CS, FitzGerald JM, Schulzer M, Mak E, Ayas NT. Does this dyspneic patient in the emergency department have congestive heart failure? JAMA. 2005; 294:1944-1956. [PubMed: 16234501]

62. Januzzi JL Jr, Camargo CA, Anwaruddin S, Baggish AL, Chen AA, Krauser DG, Tung R, Cameron R, Nagurney JT, Chae CU, Lloyd-Jones DM, Brown DF, Foran-Melanson S, Sluss PM, Lee-Lewandrowski E, Lewandrowski KB. The N-terminal Pro-BNP investigation of dyspnea in the emergency department (PRIDE) study. Am J Cardiol. 2005; 95:948-954. [PubMed: 15820160]

63. Hildebrandt P, Collinson PO, Doughty RN, Fuat A, Gaze DC, Gustafsson F, Januzzi J, Rosenberg J, Senior R, Richards M. Age-dependent values of N-terminal pro-B-type natriuretic peptide are superior to a single cut-point for ruling out suspected systolic dysfunction in primary care. Eur Heart J. 2010; 31:1881-1889. [PubMed: 20519241]

64. Januzzi JL, van Kimmenade R, Lainchbury J, Bayes-Genis A, Ordonez-Llanos J, Santalo-Bel M, Pinto YM, Richards M. NT-proBNP testing for diagnosis and short-term prognosis in acute destabilized heart failure: an international pooled analysis of 1256 patients: the International Collaborative of NT-proBNP Study. Eur Heart J. 2006; 27:330-337. [PubMed: 16293638]

65. McCullough PA, Nowak RM, McCord J, Hollander JE, Herrmann HC, Steg PG, Duc P, Westheim A, Omland T, Knudsen CW, Storrow AB, Abraham WT, Lamba S, Wu AH, Perez A, Clopton P, Krishnaswamy P, Kazanegra R, Maisel AS. B-type natriuretic peptide and clinical judgment in emergency diagnosis of heart failure: analysis from Breathing Not Properly (BNP) Multinational Study. Circulation. 2002; 106:416-422. [PubMed: 12135939]

66. Goya Wannamethee S, Welsh P, Whincup PH, Lennon L, Papacosta O, Sattar N. N-terminal pro brain natriuretic peptide but not copeptin improves prediction of heart failure over other routine clinical risk parameters in older men with and without cardiovascular disease: population-based study. Eur J Heart Fail. 2014; 16:25-32. [PubMed: 23901058]

67. Senni M, Tribouilloy CM, Rodeheffer RJ, Jacobsen SJ, Evans JM, Bailey KR, Redfield MM. Congestive heart failure in the community: a study of all incident cases in Olmsted County, Minnesota, in 1991. Circulation. 1998; 98:2282-2289. [PubMed: 9826315]

68. Vasan RS, Larson MG, Benjamin EJ, Evans JC, Reiss CK, Levy D. Congestive heart failure in subjects with normal versus reduced left ventricular ejection fraction: prevalence and mortality in a population-based cohort. J Am Coll Cardiol. 1999; 33:1948-1955. [PubMed: 10362198]

69. Kitzman DW, Gardin JM, Gottdiener JS, Arnold A, Boineau R, Aurigemma G, Marino EK, Lyles M, Cushman M, Enright PL. Cardiovascular Health Study Research Group. Importance of heart failure with preserved systolic function in patients $>65$ years of age. CHS Research Group. Cardiovascular Health Study. Am J Cardiol. 2001; 87:413-419. [PubMed: 11179524]

70. Maisel AS, McCord J, Nowak RM, Hollander JE, Wu AH, Duc P, Omland T, Storrow AB, Krishnaswamy P, Abraham WT, Clopton P, Steg G, Aumont MC, Westheim A, Knudsen CW, Perez A, Kamin R, Kazanegra R, Herrmann HC, McCullough PA. Breathing Not Properly Multinational Study Investigators. Bedside B-Type natriuretic peptide in the emergency diagnosis of heart failure with reduced or preserved ejection fraction. Results from the Breathing Not Properly Multinational Study. J Am Coll Cardio. 2003; 41:2010-2017.

71. Massie BM. Natriuretic peptide measurements for the diagnosis of "nonsystolic" heart failure: good news and bad. J Am Coll Cardiol. 2003; 41:2018-2021. [PubMed: 12798575]

72. Brouwers FP, de Boer RA, van der Harst P, Voors AA, Gansevoort RT, Bakker SJ, Hillege HL, van Veldhuisen DJ, van Gilst WH. Incidence and epidemiology of new onset heart failure with preserved vs. reduced ejection fraction in a community-based cohort: 11-year follow-up of PREVEND. Eur Heart J. 2013; 34:1424-1431. [PubMed: 23470495]

73. Anand IS, Fisher LD, Chiang YT, Latini R, Masson S, Maggioni AP, Glazer RD, Tognoni G, Cohn JN. Val-HeFT Investigators. Changes in brain natriuretic peptide and norepinephrine over time and mortality and morbidity in the Valsartan Heart Failure Trial (Val-HeFT). Circulation. 2003; 107:1278-1283. [PubMed: 12628948] 
74. Tsutamoto T, Wada A, Maeda K, Hisanaga T, Mabuchi N, Hayashi M, Ohnishi M, Sawaki M, Fujii M, Horie H, Sugimoto Y, Kinoshita M. Plasma brain natriuretic peptide level as a biochemical marker of morbidity and mortality in patients with asymptomatic or minimally symptomatic left ventricular dysfunction. Eur Heart J. 1999; 20:1799-1807. [PubMed: 10581138]

75. Masson S, Latini R, Anand IS, Vago T, Angelici L, Barlera S, Missov ED, Clerico A, Tognoni G, Cohn JN. Val-HeFT Investigators. Direct comparison of B-type natriuretic peptide (BNP) and amino-terminal proBNP in a large population of patients with chronic and symptomatic heart failure: the Valsartan Heart Failure (Val-HeFT) data. Clin Chem. 2006; 52:1528-1538. [PubMed: 16777915]

76. Jourdain P, Jondeau G, Funck F, Gueffet P, Le Helloco A, Donal E, Aupetit JF, Aumont MC, Galinier M, Eicher JC, Cohen-Solal A, Juillière Y. Plasma brain natriuretic peptide-guided therapy to improve outcome in heart failure: the STARS-BNP Multicenter Study. J Am Coll Cardiol. 2007; 49:1733-1739. [PubMed: 17448376]

77. Redfield MM, Rodeheffer RJ, Jacobsen SJ, Mahoney DW, Bailey KR, Burnett JC Jr. Plasma brain natriuretic peptide concentration: impact of age and gender. J Am Coll Cardiol. 2002; 40:976-982. [PubMed: 12225726]

78. Soualmia H, Ayadi I, Omar S, Feki M, Drissa H, Mebazaa A, Kaabachi N. Atrial natriuretic peptide and brain natriuretic peptide release in human essential hypertension. Clin Lab. 2009; 55:120-127. [PubMed: 19462934]

79. Vickery S, Price CP, John RI, Abbas NA, Webb MC, Kempson ME, Lamb EJ. B-Type natriuretic peptide and amino terminal proBNP in patients with CKD: Relationship to renal function and left ventricular hypertrophy. Amer J Kidney Dis. 2005; 46:610-620. [PubMed: 16183415]

80. Knudsen CW, Omland T, Clopton P, Westheim A, Wu AH, Duc P, McCord J, Nowak RM, Hollander JE, Storrow AB, Abraham WT, McCullough PA, Maisel A. Impact of atrial fibrillation on the diagnostic performance of B-type natriuretic peptide concentration in dyspneic patients: an analysis from the breathing not properly multinational study. J Am Coll Cardiol. 2005; 46:838844. [PubMed: 16139134]

81. Arbab-Zadeh A, Dijk E, Prasad A, Fu Q, Torres P, Zhang R, Thomas JD, Palmer D, Levine BD. Effect of aging and physical activity on left ventricular compliance. Circulation. 2004; 110:17991805. [PubMed: 15364801]

82. McCullough PA, Duc P, Omland T, McCord J, Nowak RM, Hollander JE, Herrmann HC, Steg PG, Westheim A, Knudsen CW, Storrow AB, Abraham WT, Lamba S, Wu AH, Perez A, Clopton P, Krishnaswamy P, Kazanegra R, Maisel AS. Breathing Not Properly Multinational Study Investigators. B-type natriuretic peptide and renal function in the diagnosis of heart failure: an analysis from the Breathing Not Properly Multinational Study. Am J Kidney Dis. 2003; 41:571579. [PubMed: 12612980]

83. Wang T, Larson M, Levy D, Benjamin E, Leip E, Wilson P, Ramachandran S. Impact of Obesity on Plasma Natriuretic Peptide Levels. Circulation. 2004; 109:594-600. [PubMed: 14769680]

84. Das SR, Drazner MH, Dries DL, Vega GL, Stanek HG, Abdullah SM, Canham RM, Chung AK, Leonard D, Wians FH Jr, de Lemos JA. Impact of Body Mass and Body Composition on Circulating Levels of Natriuretic Peptides: Results from the Dallas Heart Study. Circulation. 2005; 112:2163-2168. [PubMed: 16203929]

85. Frankenstein L, Remppis A, Nelles M, Schaelling B, Schellberg D, Katus H, Zugck C. Relation of $\mathrm{N}$-terminal pro-brain natriuretic peptide levels and their prognostic power in chronic stable heart failure to obesity status. Eur Heart J. 2008; 29:2634-2640. [PubMed: 18765456]

86. Krauser D, Chae C, Cameron R, Anwaruddin S, Baggish A, Chen A, Tung R, Januzzi J Jr. Effect of body mass index on natriuretic peptide levels in patients with acute congestive heart failure: A ProBNP Investigation of Dyspnea in the Emergency Department (PRIDE) substudy. Am Heart J. 2005; 149:44-50.

87. Costello-Boerrigter LC, Boerrigter G, Redfield MM, Rodeheffer RJ, Urban LH, Mahoney DW, Jacobsen SJ, Heublein DM, Burnett JC Jr. Amino-terminal pro-B-type natriuretic peptide and Btype natriuretic peptide in the general community: determinants and detection of left ventricular dysfunction. J Am Coll Cardiol. 2006; 47:345-353. [PubMed: 16412859] 
88. Sugisawa T, Kishimoto I, Makino H, Miyamoto Y, Yoshimasa Y. Association of plasma B-type natriuretic peptide levels with obesity in a general urban Japanese population: the Suita study. Endocrine Journal. 2010; 57:727-733. [PubMed: 20519808]

89. Tsutamoto T, Wada A, Sakai H, Ishikawa C, Tanaka T, Hayashi M, Fujii M, Yamamoto T, Dohke T, Ohnishi M, Takashima H, Kinoshita M, Horie M. Relationship between renal function and plasma brain natriuretic peptide in patients with heart failure. J Am Coll Cardiol. 2006; 47:582586. [PubMed: 16458140]

90. Griffin KA, Kramer H, Bidani AK. Adverse renal consequences of obesity. Am J Physiol Renal Physiol. 2008; 294:F685-F696. [PubMed: 18234955]

91. Sengenes C, Berlan M, De Glisezinski I, Lafontan M, Galitzky J. Natriuretic peptides: a new lipolytic pathway in human adipocytes. FASEB J. 2000; 14:1345-1351. [PubMed: 10877827]

92. Kalra PR, Tigas S. Regulation of lipolysis: natriuretic peptides and the development of cachexia. Int J Cardiol. 2002; 85:125-132. [PubMed: 12163217]

93. Fox CS, Massaro JM, Hoffmann U, Pou KM, Maurovich-Horvat P, Liu CY, Vasan RS, Murabito JM, Meigs JB, Cupples LA, D’Agostino RBSr, O’Donnell CJ. Abdominal visceral and subcutaneous adipose tissue compartments: association with metabolic risk factors in the Framingham Heart Study. Circulation. 2007; 116:39-48. [PubMed: 17576866]

94. Cheng S, Fox CS, Larson MG, Massaro JM, McCabe EL, Khan AM, Levy D, Hoffmann U, O’Donnell CJ, Miller KK, Newton-Cheh C, Coviello AD, Bhasin S, Vasan RS, Wang TJ. Relation of visceral adiposity to circulating natriuretic peptides in ambulatory individuals. Am J Cardiol. 2011; 108:979-984. [PubMed: 21813106]

95. Trevisan R, Fioretto P, Semplicini A, Opocher G, Mantero F, Rocco S, Remuzzi G, Morocutti A, Zanette G, Donadon V, Perico N, Giorato C, Nosadini R. Role of insulin and atrial natriuretic peptide in sodium retention in insulin-treated IDDM patients during isotonic volume expansion. Diabetes. 1990; 39:289-298. [PubMed: 2137801]

96. Abouchacra S, Baines AD, Zinman B, Skorecki KL, Logan AG. Insulin blunts the natriuretic action of atrial natriuretic peptide in hypertension. Hypertension. 1994; 23:1054-1058. [PubMed: 8206593]

97. Tanabe A, Naruse M, Wasada T, Naruse K, Yoshimoto T, Omori Y, Demura H. Effects of acute hyperinsulinemia on plasma atrial and brain natriuretic peptide concentrations. Eur J Endocrinol. 1995; 132:693-698. [PubMed: 7788008]

98. Tokudome T, Horio T, Yoshihara F, Suga S, Kawano Y, Kohno M, Kangawa K. Direct effects of high glucose and insulin on protein synthesis in cultured cardiac myocytes and DNA and collagen synthesis in cardiac fibroblasts. Metabolism. 2004; 53:710-715. [PubMed: 15164316]

99. Cabiati M, Raucci S, Liistro T, Belcastro E, Prescimone T, Caselli C, Matteucci M, Iozzo P, Mattii L, Giannessi D, Del Ry S. Impact of obesity on the expression profile of natriuretic peptide system in a rat experimental model. PLoS One. 2013; 8:e72959. [PubMed: 24009719]

100. Potter LR, Abbey-Hosch S, Dickey DM. Natriuretic peptides, their receptors, and cyclic guanosine monophosphate-dependent signaling functions. Endocr Rev. 2006; 27:47-72. [PubMed: 16291870]

101. Kuhn M. Structure, regulation, and function of mammalian membrane guanylyl cyclase receptors, with a focus on guanylyl cyclase-A. Circ Res. 2003; 93:700-709. [PubMed: 14563709]

102. Miyashita K, Itoh H, Tsujimoto H, Tamura N, Fukunaga Y, Sone M, Yamahara K, Taura D, Inuzuka M, Sonoyama T, Nakao K. Natriuretic peptides/cGMP/cGMP-dependent protein kinase cascades promote muscle mitochondrial biogenesis and prevent obesity. Diabetes. 2009; 58:2880-2892. [PubMed: 19690065]

103. Sarzani R, Strazzullo P, Salvi F, Iacone R, Pietrucci F, Siani A, Barba G, Gerardi MC, DessìFulgheri P, Rappelli A. Natriuretic peptide clearance receptor alleles and susceptibility to abdominal adiposity. Obes Res. 2004; 12:351-356. [PubMed: 14981229]

104. Moro C, Smith SR. Natriuretic peptides: new players in energy homeostasis. Diabetes. 2009; 58:2726-2728. [PubMed: 19940236]

105. Bordicchia M, Liu D, Amri EZ, Ailhaud G, Dessì-Fulgheri P, Zhang C, Takahashi N, Sarzani R, Collins S. Cardiac natriuretic peptides act via p38 MAPK to induce the brown fat thermogenic 
program in mouse and human adipocytes. J Clin Invest. 2012; 122:1022-1036. [PubMed: 22307324]

106. Nisoli E, Tonello C, Cardile A, Cozzi V, Bracale R, Tedesco L, Falcone S, Valerio A, Cantoni O, Clementi E, Moncada S, Carruba MO. Calorie restriction promotes mitochondrial biogenesis by inducing the expression of eNOS. Science. 2005; 310:314-317. [PubMed: 16224023]

107. Civitarese AE, Carling S, Heilbronn LK, Hulver MH, Ukropcova B, Deutsch WA, Smith SR, Ravussin E. CALERIE Pennington Team. Calorie restriction increases muscle mitochondrial biogenesis in healthy humans. PLoS Med. 2007; 4(3):e76. [PubMed: 17341128]

108. Lafontan M, Moro C, Sengenes C, Galitzky J, Crampes F, Berlan M. An unsuspected metabolic role for atrial natriuretic peptides: the control of lipolysis, lipid mobilization, and systemic nonesterified fatty acids levels in humans. Arterioscler Thromb Vasc Biol. 2005; 25:2032-2042. [PubMed: 16123323]

109. Sengenes C, Bouloumie A, Hauner H, Berlan M, Busse R, Lafontan M, Galitzky J. Involvement of a cGMP-dependent pathway in the natriuretic peptide-mediated hormone-sensitive lipase phosphorylation in human adipocytes. J Biol Chem. 2003; 278:48617-48626. [PubMed: 12970365]

110. Choquet H, Cavalcanti-Proença C, Lecoeur C, Dina C, Cauchi S, Vaxillaire M, Hadjadj S, Horber F, Potoczna N, Charpentier G, Ruiz J, Hercberg S, Maimaitiming S, Roussel R, Boenhnke M, Jackson AU, Patsch W, Krempler F, Voight BF, Altshuler D, Groop L, Thorleifsson G, Steinthorsdottir V, Stefansson K, Balkau B, Froguel P, Meyre D. The T-381C SNP in BNP gene may be modestly associated with type 2 diabetes: an updated meta-analysis in 49279 subjects. Hum Mol Genet. 2009; 18:2495-2501. [PubMed: 19377085]

111. Costello-Boerrigter LC, Boerrigter G, Ameenuddin S, Mahoney DW, Slusser JP, Heublein DM, Redfield MM, Rodeheffer RJ, Olson TM, Burnett JC Jr. The effect of the brain-type natriuretic peptide single-nucleotide polymorphism rs198389 on test characteristics of common assays. Mayo Clin Proc. 2011; 86:210-218. [PubMed: 21364112]

112. Pfister R, Luben RN, Khaw KT, Wareham NJ. Common genetic variants of the natriuretic peptide gene locus are not associated with heart failure risk in participants in the EPIC-Norfolk study. Eur J Heart Fail. 2013; 15:624-627. [PubMed: 23315043]

113. St Peter JV, Hartley GG, Murakami MM, Apple FS. B-type natriuretic peptide (BNP) and Nterminal pro-BNP in obese patients without heart failure: relationship to body mass index and gastric bypass surgery. Clin Chem. 2006; 52:680-685. [PubMed: 16497939]

114. Changchien EM, Ahmed S, Betti F, Higa J, Kiely K, Hernandez-Boussard T, Morton J. B-type natriuretic peptide increases after gastric bypass surgery and correlates with weight loss. Surg Endosc. 2011; 25:2338-2343. [PubMed: 21424205]

115. Chainani-Wu N, Weidner G, Purnell DM, Frenda S, Merritt-Worden T, Kemp C, Kersh E, Ornish D. Relation of B-type natriuretic peptide levels to body mass index after comprehensive lifestyle changes. Am J Cardiol. 2010; 105:1570-1576. [PubMed: 20494664]

116. Christenson R, Duh SH. Impact of Increased Body Mass Index on Accuracy of B-Type Natriuretic Peptide (BNP) and N-Terminal proBNP for Diagnosis of Decompensated Heart Failure and Prediction of All-Cause Mortality. Clinical Chemistry. 2010; 56:633-641. [PubMed: 20167699]

117. Bayes-Genis A, Lloyd-Jones DM, van Kimmenade RR, Lainchbury JG, Richards AM, OrdoñezLlanos J, Santaló M, Pinto YM, Januzzi JL Jr. Effect of body mass index on diagnostic and prognostic usefulness of amino-terminal pro-brain natriuretic peptide in patients with acute dyspnea. Arch Intern Med. 2007; 167:400-407. [PubMed: 17325303] 


\section{Highlights}

- The biology, physiology, and pathophysiology of BNP and NT-proBNP peptides and cardiac endocrine paradox in heart failure was examined.

- The diagnostic and prognostic value of BNP and NT-proBNP levels in heart failure was enumerated.

- The discord between BNP levels and heart failure in obese patients was discussed, with validation of new cut points.

- Plausible mechanisms and biological explanations for the discord between BNP levels and heart failure in obese patients were proposed. 


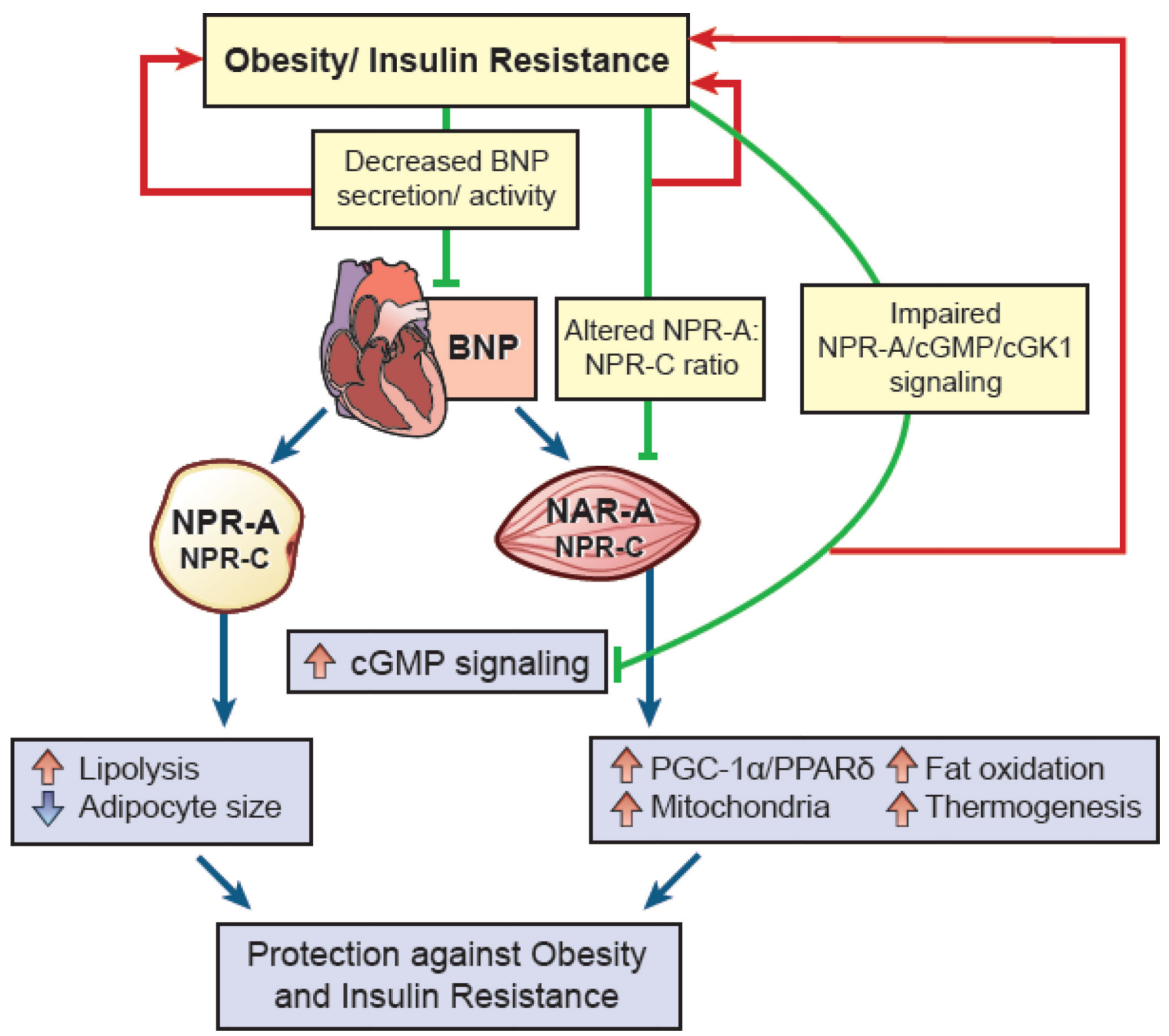

Fig. 1.

A proposed bidirectional relationship between BNP and obesity. Under normal conditions, BNP acting through the NPR-A receptor induces cGMP signaling which promotes lipolysis in adipose tissue and mitochondrial biogenesis and fat oxidation in skeletal muscle. These physiological actions provide protection against obesity and insulin resistance. Contrast to this, in obese patients and people with insulin resistance BNP secretion and activity are decreased and NPR-A:NPR-C ratio is altered, impairing NPR-A/cGMP/cGK1 signaling, as also reported during high fat feeding and/or physical inactivity [adapted from Moro and Smith, 104]. 


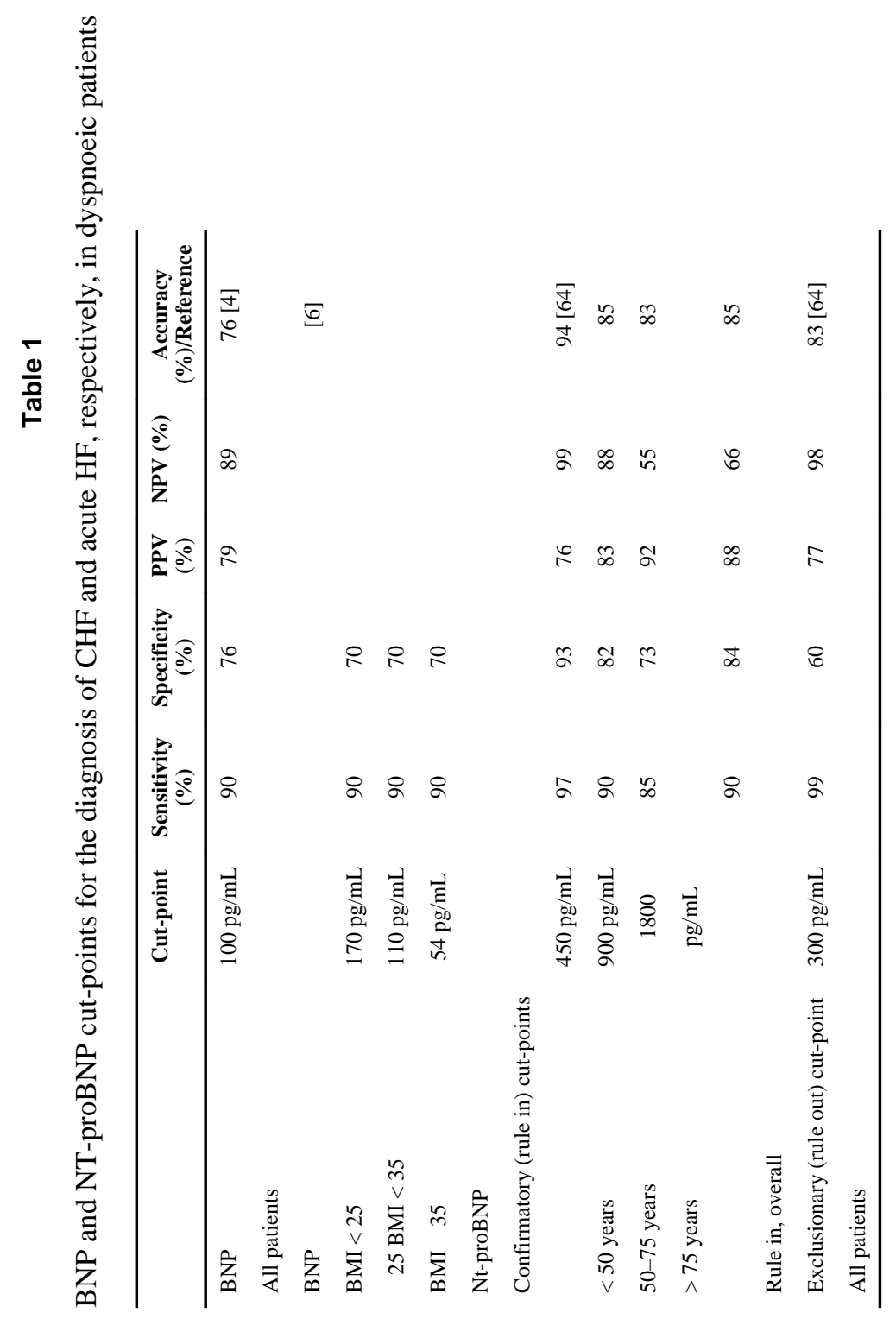

